\title{
SOCIOLOG RELIGIJE I ČOVEK DIJALOGA, IVAN CVITKOVIĆ
}

Akademik dr Ivan Cvitković, ${ }^{1}$ profesor emeritus, objavio je 34 knjige, što svedoči o bogatoj naučnoj delatnosti, koja je naučnoj javnosti dobro poznata. Radeći na istom poslu profesora sociologije religije u Novom Sadu, godinama sam studente upućivala na udžbenike profesora Cvitkovića i rado smo čitali i pozivali se u svojim radovima na tekstove koje je napisao. Takođe, slušala sam brojna izlaganja profesora Cvitkovića na konferencijama i svedočim o čoveku koji zna svoj posao, o čoveku koji celim bićem zrači kulturom dostojanstva i kulturom dijaloga.

Za ovu priliku izdvajam jednu knjigu - Moj susjed musliman (Cvitković 2011a) - kojom nam odnose između hrišćana i muslimana dodatno osvetljava. Osim naučnog diskursa, koji mu omogućava da bude objektivan posmatrač i pošten u imenovanju pojmova koji proizlaze iz konteksta posmatrane pojave, Ivan Cvitković poseduje i lično iskustvo života i rada u Bosni i Hercegovini, u Sarajevu, u ratu i miru, u dobru i zlu.

Odgovore na brojna pitanja koja u knjizi postavlja Ivan Cvitković pronalazi u bogatoj literaturi, u istorijskim činjenicama, u empirijskim istraživanjima i porodičnom vaspitanju. Jedno od značajnih pitanja postavljenih u ovome delu jeste da li muslimani i hrišćani veruju u istog Boga. Odgovarajući na ovo pitanje Ivan Cvitković najpre kaže: "Moja majka, danas devedesetogodišnja starica, katolkinja, uvijek mi je govorila: Bog je jedan, samo su se vjere podijelile" (Cvitković 2011a: 74). Zatim navodi da se ovo pitanje ne prepoznaje kao problem među muslimanima i hrišćanima koji žive na arapskom govornom području: i jedni i drugi Boga nazivaju istom rečju "Alah" (Cvitković 2011a: 73). Sam naslov ove knjige - Moj susjed musliman - upućuje nas na pitanje religijskog identiteta drugog. Izvori za upoznavanje druge religije mogu biti svete knjige, učenja i pravila o životu - što čini teorijsku ravan pro-

\footnotetext{
${ }^{1}$ Godinama unazad, svoj radni vek akademik Ivan Cvitković posvetio je afirmaciji znanja o svim religijama predajući na Sarajevskom univerzitetu Sociologiju religije. Od brojnih tekstova i knjiga izdvajamo one koje su nam dostupne iz odnosa saradnje: Religija i identitet (2011b), Sociologija religije (1996), Sociološki pogledi na naciju i religiju II (2012), Religija u zrcalu teorija (2016), Sociološki pogledi na naciju i religiju III (2017).
} 
blema; uz to, međutim, i sledbenici određenih religija svedoče o sebi samima. Zato autor, ne skrivajući sopstveni identitet niti sopstvenu motivaciju za pisanje ove knjige, beleži: "Autor je imao sreću da se koristi obama načinima: upoznavanjem s izvorima kršćanstva i islama, a kao osoba čija nasleđena kultura potječe iz kršćanskih izvora, od osnovne je škole imao sreću školovati se, družiti, raditi, živjeti zajedno i s kršćanima i s muslimanima (Mostar/ Sarajevo), sve do osobnih i obiteljskih prijateljstava" (Cvitković 2011a: 16).

Jasno je da je skoro svaka praksa izdaja učenja na kojima se zasniva, odnosno da govor, na sociološkoj ravni, o muslimanima i hrišćanima zahteva vrlo veliku pažnju, naročito prilikom zaključivanja. Ivan Cvitković uspešno se bavi problemom odnosa muslimana i hrišćana unoseći dijalošku metodu u razmatranje skoro svakog problema. Jedan od njih je pitanje da li su islam i hrišćanstvo ono što bi muslimani i hrišćani trebalo da čine ili ono što oni čine. Za sociologa, odgovor je: ono što oni čine, naglašava autor (Cvitković 2011a: 58). A dela jednih i drugih posmatrana u istorijskoj i transverzalnoj perspektivi merljiva su na različite načine, što ova knjiga takođe osvetljava. S kritičkom distancom autor se dotiče primera netolerancije i provokacija, ne štedeći nijednu stranu. Isto tako, iznosi primere tolerancije, $\mathrm{i}$ to kako $\mathrm{u}$ istorijskom kontekstu tako i polazeći od savremenih dešavanja, naglašavajući pri tome da je metoda uzimanja samo ekstremnih slučajeva iz života i muslimana i hrišćana apsolutno neprihvatljiva - u protivnom će i ovo stoleće nastaviti s praksom prethodnog: progoniti i uništavati ljude samo zbog toga što pripadaju drugačijoj religijskoj kulturi (Cvitković 2011a: 180).

"Zato i pišem ove retke da bismo shvatili da se i kršćani i muslimani trebaju uzdići iznad povijesnih nesporazuma i u XXI stoljeću živjeti uz međusobno prihvaćanje, poštovanje i zajedničko djelovanje na nizu životnih pitanja" (Cvitković 2011a: 128). Ivan Cvitković i svoje studente žurnalistike, u Sarajevu, uči da u medijima ne objavljuju priloge koji bi mogli vređati verska osećanja: "Uvijek treba imati na umu da religijska netrpeljivost, nepoštovanje i kršenje prava na slobodu misli, savjesti i vjeroispovijesti vodi u diskriminaciju, progonstvo, rat i smrt" (Cvitković 2011a: 188). U tom kontekstu autor navodi brojne primere manipulacija u medijima, koje su formirale atmosferu straha i mržnje, i tvrdi kako se iza toga uvek kriju neki posve neduhovni ciljevi. Ključne reči u ovoj knjizi su dijalog i tolerancija, kao vapaj za mirom, dok, s druge strane, reč nasilje, učestalošću pojavljivanja, upozorava na tamnu stranu svakodnevice.

Uvid u spisak literature - a knjiga i zbornika ima preko 300, čemu treba dodati i brojne časopise i članke kao izvore - takođe nudi zanimljive podatke. Vidimo, tako, da je 31\% knjiga štampano u Srbiji, najviše u Beogradu, potom 
25\% u Hrvatskoj, pretežno u Zagrebu, i 24\% u Bosni i Hercegovini, najviše u Sarajevu. Ostalih 20\% čine knjige izvan ovog našeg govornog područja i mesta susretanja.

Knjiga ima 300 stranica, a razdeljena je na 18 poglavlja, koja donose sledeće teme: šta bi Evropljanin trebalo da zna o islamu; stanje među muslimanima; politička kretanja među muslimanima; sličnosti i razlike u verovanjima hrišćana i muslimana, moralne vrednosti, pouke i poruke islama i hrišćanstva; odnos hrišćana na Zapadu prema islamu i muslimanima; odnos muslimana prema Zapadu, hrišćanstvu i hrišćanima; islam i hrišćanstvo u kontekstu demokratije i verskih sloboda; muslimani u Evropi i Evropskoj uniji; "evropski islam" ili islam u Evropi; konflikti i/ili nesporazumi; kontroverze oko pojma "džihad"; marama, zašto ne; društveni status muslimanke; kontroverze oko vehabizma; u terorizmu je religija oteta; šta raditi?

U poglavlju o muslimankama autor polazi od premise da je položaj žene danas više rezultat njenog društvenog statusa nego religije, islama. "Ostavimo po strani prirodnu nejednakost među spolovima (žena rađa, muškarac oplođuje). Nas zanima društveni status žene" (Cvitković 2011a: 233). A on je, izgleda, više pod uticajem kulturne tradicije određenog geografskog prostora, a manje rezultat islamskog učenja: "Kao što ne postoji jednoobrazni muslimanski svijet, tako ne postoje ni jednoobrazni modeli položaja žena $\mathrm{u}$ tom svijetu / tim svjetovima. Taj se položaj kreće, s jedne strane, od zabrane kretanja (bez muške pratnje), školovanja, rada, glasanja - do, s druge strane, sudjelovanja žena u javnim poslovima, političkim i kulturnim elitama, visokoobrazovanim ekspertima za pojedina područja života i rada itd. Nije li Poslanik zaštitio ženu od muškarčeve samovolje (Najbolji među vama su oni koji su najbolji svojim ženama)?" (Cvitković 2011a: 243).

$\mathrm{Na}$ kraju poglavlja pod naslovom "U terorizmu je religija oteta" autor kaže: "Koristiti se religijom kao poticajem za nasilje najgori je oblik narušavanja etičkih vrednota religije. Može li se to nazvati samo zloupotrebom religije? Drugi će reći da i nema smisla to vezivati za religiju jer nije riječ o religiji, nego o njenoj 'izdaji'. Ali kao što se Katolička crkva ne može osloboditi odgovornosti za inkviziciju, križarske ratove, animozitet prema Židovima sve do progonstva, nasilja u misionarenju, potpori diktaturama i sl., tako se ni islamska ulema i muslimanske zajednice ne mogu osloboditi odgovornosti za dio nasilja koji se danas čini u ime islama. Sociolozi i religiolozi bi rekli: islam nije ni nasilan ni nenasilan, ali to može postati čim se instrumentalizira za nasilnu politiku. Nenasilje je znak jakosti vjere, isto kao što je nasilje oličeno u terorizmu znak slabosti vjere. Je li u terorizmu religija oteta?" (Cvitković 2011a: 265). 
Šta raditi?

Ako nam je mudrost tražiti u verskim spisima, autor navodi stih iz Poslanice Rimljanima 12:10, gde se savetuje: "U davanju časti prednjačite jedan drugomu”, pa iz Kur'ana V:2: “Jedni drugima pomažite u dobročinstvu i čestitosti." Ako ćemo se učiti od filozofa i mudraca među nama, oslušnuti treba reči profesora Đure Šušnjića: "Izgleda da su dijalog i tolerancija jedini lek za sve boljke društvenog života." Ivo Cvitković, na kraju, gledajući okom sociologa religije zaključuje: "Nema dvojbe da kršćanski i muslimanski zemljopis mogu biti izvor konflikata: isticanje kako su kršćani gradili (i grade) crkve na svetim muslimanskim mjestima, i obratno, kako su muslimani gradili (i grade) džamije na svetim kršćanskim mjestima. Tomu treba dodati želju da se vidljivo, podizanjem velikih križeva i velikih crkvenih tornjeva s jedne, visokih munara, s druge strane, pokaže i obilježi svoj teritorij, svoja granica koju drugi ne treba prelaziti. Za toleranciju je bitno da kod vjernika, bez obzira na to bili kršćani ili muslimani, prevladava svijest o ravnopravnosti religija" (Cvitković 2011a: 267).

Lepo je na jednom mestu naći i pročitati sva mišljenja i značenja pojma tolerancija, koja autor na kraju knjige daje, čime ih dodatno približava i konkretizuje, radi lakše primene. Biram samo još jedan citat zato što dodatno osvetljava i druga poglavlja, najpre ona u kojima se detaljno navode primeri međusobnih odnosa vernika unutar iste religije, a ne samo između suseda.

"Tolerancija nije samo pitanje odnosa prema pripadnicima drugih religija i konfesija, ona podrazumijeva i poštovanje slobode pripadnika vlastite religijske grupe da, ako želi, napusti tu religiju bez ikakvih posljedica. A kako kršćani i muslimani gledaju na one koji su napustili grupu (recimo, ateiste), ili prešli u drugu (kršćanin na islam, musliman na kršćanstvo)? Neka na to pitanje odgovori samom sebi svaki musliman i svaki kršćanin. Neka, na osnovi toga, za sebe ocijeni je li, i koliko, (ne)tolerantan. Od netolerancije prema pripadnicima druge religije, samo je veća netolerancija prema otpadnicima od svoje vjere" (Cvitković 2011a: 273).

Ivan Cvitković, u knjizi koja se bavi sociološkim pogledima na religiju i naciju, objavljuje Intervju koji nikad nije objavljen u kome mu je novinar Katoličkog tjednika postavio pitanje: "Na koji način objašnjavate konflikte u svijetu, pa i Bosni i Hercegovini, uzrokovane vjerskom netrpeljivošću, ako se zna da većina religija propagira toleranciju?" Cvitković kaže da postoje neke nepobitne činjenice, a to je da su sve religije iskusile nasilje, posebno u svom početku kada su bile proganjane, potom, sve su kroz istoriju primenjivale nasilje, i konačno, u ime religije proliveno je mnogo krvi. Međutim, nasilje je izdaja religije, izdaja od njenih sledbenika. "Jedno je što religije kažu, a drugo je kako sljedbenici religije žive te vrijednosti, koliko ih u životu slijede. Pa 
i one vrijednosti koje se tiču tolerancije. Sociolozi, ali i obični svijet, rijetko religiju procjenjuju na osnovu 'svetih spisa', već po ponašanju vjernika. Niko ne može kompromitirati kršćanstvo i islam kao sami krišćani i muslimani. Možda je problem i u interpretiranju izvora. Onaj tko hoće mir, nenasilje, naći će dosta mjesta u pisanim izvorima svoje religije kojima će moći to opravdati, braniti." (Cvitković 2012: 346).

Posao sociologa religije i jeste da prati realni život, religiju u sociološkom kontekstu, u obredima, ponašanju, moralu, a ne samo u učenju. Verska učenja su zvezda vodilja, ali čini se daleka, za mnoge, ipak, prisutna u svim kulturama, u svim zajednicama. A lepota života u Sarajevu bila je upravo u bogatstvu četiri varijante monoteizma koje je poput četiri Jevanđelja nudilo kulturu dijaloga.

Upravu tu kulturu dijaloga neguje u svojim knjigama i u svom životu akademik Ivan Cvitković, braneći univerzalne vrednosti koje povezuju ljude, poput religije, čija je to osnovna funkcija.

\section{Literatura}

Cvitković, Ivan (1996), Sociologija religije, Edicija Univerzitetska knjiga, Ministarstvo obrazovanja, nauke, kulture i sporta, Sarajevo.

Cvitković, Ivan (2011a), Moj susjed musliman, Školska knjiga, Zagreb.

Cvitković, Ivan (2011b), Religija i identitet, Diskursi: društvo, religija i kultura, Sarajevo, god. I, br. 1, str. 11-27.

Cvitković, Ivan (2012), Sociološki pogledi na naciju i religiju II, Centar za empirijska istraživanja religije u Bosni i Hercegovini, Sarajevo.

Cvitković, Ivan (2016), Religija u zrcalu teorija, Centar za empirijsko istraživanje religije CEIR, Sarajevo.

Cvitković, Ivan (2017), Sociološki pogledi na naciju i religiju III, Štamparija Fojnica, Fojnica. 